\title{
An Integrated Neural Network Algorithm for Optimum Performance Assessment of Auto Industry with Multiple Outputs and Corrupted Data and Noise
}

\author{
M.Saberi ${ }^{\text {a }}$, A.Azadeh ${ }^{\text {b }}$, S.Tofighi ${ }^{\text {b }}$,P.Pazhoheshfar ${ }^{\text {c }}$ \\ ${ }^{a}$ Institute for Digital Ecosystems \& Business Intelligence, Curtin University of Technology, Perth, Australia \\ ${ }^{b}$ Department of Industrial Engineering, Center of Excellence for Intelligent-Based Experimental Mechanics, College of \\ Engineering, University of Tehran, Iran \\ ${ }^{\mathrm{c}}$ Young Researchers Club, Tafresh Branch, Islamic Azad University,Tafresh, Iran \\ Mortezza_saber@yahoo.com, Aazadeh@ut.ac.ir,P.Pazhohesh@gmail.com
}

\begin{abstract}
In the real world encountering with noisy and corrupted data is unavoidable. Auto industry sector (AIS) as a one of the significant industry encounters with noisy and corrupted data regarding to its rapid development. Therefore, developing the performance assessment in this situation is so helpful for this industry. As Data envelopment Analysis (DEA) could not deal with noisy and corrupted data, the alternative method(s) is very important. As one of excellent and promising feature of artificial neural networks (ANNs) are theirs flexibility and robustness in noisy situation, they are a good alternative. This study proposes a non-parametric efficiency frontier analysis method based on the adaptive neural network technique for measuring efficiency as a complementary tool for the common techniques for efficiency assessment in the previous studies. The proposed computational method is able to find a stochastic frontier based on a set of input-output observational data and do not require explicit assumptions about the function structure of the stochastic frontier. In this algorithm, for calculating the efficiency scores of auto industry in various countries, a similar approach to econometric methods has been used. Moreover, the effect of the return to scale of AIS on its efficiency is included and the unit used for the correction is selected by notice of its scale (under constant return to scale assumption). Another feature of proposed algorithm is its ability to calculate efficiency for multiple outputs. An example using real data is presented for illustrative purposes. In the application to the auto industries, we find that the neural network provide more robust results and identifies more efficient units than the conventional methods since better performance patterns are explored. To test the robustness of the efficiency results of the proposed method, the ability of proposed ANN algorithm in dealing with noisy and corrupted data is compared with Data Envelopment Analysis (DEA). Results of the robustness check show that the proposed algorithm is much more robust to the noise and corruption in input data than DEA.
\end{abstract}

\section{INTRODUCTION}

Main factors influencing the overall productivity of an organization are identified as technology, machinery, management, personnel and rules and procedures (Azadeh, 2000[1]). Managerial and economic factors play an important role in the overall performance of a particular industrial sector. The need for an integrated approach for continuous assessment and improvement of communication sectors based on managerial performance has become essential. Continuous assessment requires classifications and taxonomy to be introduced to enhance knowledge and understanding about the behavior of communication systems. Consequently, it will enable predictions to be made about organizational system behavior. In a real world situation, there exist peer groups of decision making units (DMUs), such as, auto industry sector which use various resources (inputs) to generate various results (outputs). We want to know the overall performance of auto industry sector by their inputs consumed and outputs generated. It is desirable that we are able to combine various inputs and outputs into one measure, such as the ratio of aggregated outputs to aggregated inputs, so that we can evaluate and rank the performance of AISs by the corresponding single measure. Auto industry is the one of important industry in the life of people in the world with high demand. For example, a total of 71.9 million automobiles were sold in 2007 in the worldwide (Wiki). The rapid development in the auto industry sector regarding to its profitability and also the competition between auto manufacturer leads to noisy and corrupted data in this industry. The probability of existing noise in the data of auto industry leads to using some flexible tools to analysis the industry. This study presents an integrated artificial neural network by noting the important role of auto industry.

Parametric and nonparametric approaches are two competing paradigms on performance assessment. The first include the estimation of both deterministic and stochastic frontier functions. The latter include data envelopment analysis (DEA) which is based on a mathematical programming approach.

Features of first methods have been studied in the work of Azadeh et al., 2011[2]. However, they don't develop the algorithm to deal with noisy data.

Data envelopment analysis (DEA) is a good solution to evaluate the performance of systems in a multi input-multi output environment. DEA is one popular optimization method used for measuring the relative efficiency of DMUs. Also, it 
is used in extensive area. Seiford, 1997 prepared a bibliography for DEA and listed 800 papers on DEA from 1978 to $1996[3]$.

The assumptions made for each of parametric and nonparametric methods are restrictive. The parametric method makes assumption about the functional form of the frontier and nonparametric method frontier (for example DEA) is very sensitive to the presence of the outliers and statistical noise. In following some of recent papers in DEA have been analyzed and is shown that sensitivity problem was not removed.

Hung et al., 2011 have used balanced scorecard to developing a set of performance evaluation indices for extension education centers in universities[4]. However, this approach only determines the important features in performance of decision making units and cannot rank between them. Performance assessment of cooling tower is analyzed by Statistical multi-model by Pan et al., 2011[5]. However, in this study again one type of cooling tower have used and ranking issue did not considered. Lu et al., 2011, have studied the air quality monitoring networks of Hong Kong [6]. They have used principal component analysis and cluster analysis as a two statistical methods and conclude that the used methods would be beneficial for air quality monitoring networks. However, again we cannot see the any ranking and optimization issue in this study. Hollingsworth et al., 1999, have reviewed the literature that is related to productive performance of health care services [7]. They conclude that public rather than private provision is better based on USA and Euro evidences. Also, they proposed some suggestion to better use of DEA. However, they don't considering other approaches in the literature of performance assessment. Hollingsworth, 2003, have reviewed the 180 papers on performance assessment of health care [8]. They consider non parametric and parametric approaches but did not point to artificial intelligence approach as parametric approach. Camanho and Dyson, 2006, developed measure “enable the decision making units' internal inefficiencies to be distinguished from those associated with their group (or program) characteristics" [9]. The case study of their works is bank branches. However, they don't consider any approach to deal with DEA sensitivity to noise as a banking system encounter with noisy environment. Yang et al. have used DEA in Supply chain domain [10]. They tried to determine corresponding production possibility set". The contribution of their works is to "exact definition for supply chain production possibility set". The shortcoming of their works is lack other performance assessments methods.

ANNs are a promising alternative to conventional approaches, econometric models and non-parametric methods such as DEA, to fit production functions and measure efficiency under non-linear contexts. The main aim of this note is to study the performance of ANN for performance assessment of AIS in the noisy environment. The neural networks, universal aproximators of functions and its derivates, are non linear (free-model and no assumptions about the functional form that links its inputs to outputs), stochastic techniques and highly flexible models and it is theoretically possible to make statistical inference such as interval confidence to inefficiency indexes, and hence they provide a good instrument for these purposes. The few study in this filed did not study the features and capability of ANN in noisy environment (Athanassopoulos and Curram, 1996 [11]; Costa and Markellos, 1997 [12]; Santın and Valin, 2000[13]).

This study proposes a non-parametric efficiency frontier analysis method based on the adaptive neural network technique for evaluating the performance of auto industries in some selected countries around the world in the years 1995 to 2000. To this end, for estimating production function, ANN method has been applied and for calculating the efficiency scores, a similar approach to econometric methods has been used.

The paper is organized as follows. Section II is dedicated to ANNs in efficiency analysis and an algorithm is proposed in this section for assessing efficiency of AISs. An empirical illustration for measuring performance of auto industries is carried out in Section III. The result and error analysis are studied in section VI. Also, the final section of the paper offers conclusions.

\section{METHODOLOGY}

An integrated algorithm is proposed to evaluate the efficiency scores of auto industry sector (AIS) in noisy and corrupted environments as follows.

1. Determination input $(s)$ and output $(P)$ variables of the model that are related to the AIS. The numbers of outputs are equal to $L$.

2. Collecting data set $S$ in all available previous periods which describes the input-output periods which describes the input-output relationship for AISs. Assume that there are $n$ auto industry sectors (AISs) to be evaluated. Note that the current period data $\left(S_{c}\right)$ which evaluation will have been done on them, do not belong to $S$.

3. Improve the accuracy of ANN by preprocessing the raw data.

4. Divide $\mathrm{S}$ in to two subsets: training $\left(S_{1}\right)$ and test $\left(S_{2}\right)$ data.

5. Use ANN method to estimate relation between input(s) and output(s). For this reason follow these steps:

- $\quad$ Select architecture and training parameters.

- Train the model using the training data $\left(S_{l}\right)$.

- Evaluate the model using the test data $\left(S_{2}\right)$.

- Repeat these steps using different architectures and training parameters.

- $\quad$ Select the best network architecture $\left(\mathrm{ANN}^{*}\right)$ from the testing data error (Mean Absolute Percentage Error(MAPE)).

6. Run $\mathrm{ANN}^{*}$ for $S_{c}$.

7. Do following steps for output $\mathrm{j}^{\text {th }}: \mathrm{j}=1, . ., L$ 
8. Calculate weigh of $\operatorname{AIS}_{i}\left(W_{i}\right)$ :

$$
\begin{aligned}
& \mathrm{V}_{\mathrm{ij}}=\mathrm{P}_{\mathrm{ij}} / \operatorname{Average}\left(\mathrm{P}_{\mathrm{ij}}, \ldots, \mathrm{P}_{(\mathrm{i}-1) \mathrm{j}}, \mathrm{P}_{(\mathrm{i}+1) \mathrm{j}}, \ldots, \mathrm{P}_{\mathrm{nj}}\right) \\
& \mathrm{W}_{\mathrm{ij}}=\mathrm{V}_{\mathrm{ij}} / \sum_{i=1}^{n}\left(\mathrm{~V}_{\mathrm{ij}}\right)
\end{aligned}
$$

9. Calculate the error between the real output $\left(P_{\text {real }(i j)}\right)$ and ANN model output $\left(P_{A N N^{*}(i j)}\right)$ in the period which you want to assess the efficiency of its AISs $\left(S_{c}\right)$ :

$$
\begin{aligned}
& \mathrm{E}_{\mathrm{ij}}=P_{\text {real }(\mathrm{jij})}-P_{\mathrm{ANN} *(\mathrm{ij})} \\
& i=1, \ldots, n
\end{aligned}
$$

10. Shift frontier function from neural network for obtaining the effect of the largest positive error which is one of the unique features of this algorithm:

$$
\mathrm{E}_{0}{ }^{\prime}=\mathrm{E}_{\mathrm{ij}} / \mathrm{W}_{\mathrm{ij}} i=1, \ldots, n
$$

This option consists of not considering the largest error, but calculates by noting the AIS scale (Constant Returns to Scale (CRS)). To this end find:

The largest $E_{0}^{\prime}$ indicate the DMU with the best performance. Suppose that $\mathrm{AIS}_{k}$ have the Largest $E_{0}^{\prime}$ and we have:

$$
\mathrm{E}_{\mathrm{kj}}{ }^{\prime}=\max \left(\mathrm{E}_{\mathrm{i}}{ }^{\prime}\right)
$$

So, the value of the shift for each of the AISs is different and is calculated in (5):

$$
\mathrm{Sh}_{\mathrm{ij}}=\mathrm{E}_{\mathrm{kj}} * \mathrm{~W}_{\mathrm{ij}} / \mathrm{W}_{\mathrm{kj}} i=1, \ldots, n
$$

In this approach in spite of the previous studies (Athnassopoulos and Curram, 1996 called this measure "standardized efficiency" [11]) the effect of the scale of AISs on its efficiency is considered and the unit used for the correction is selected by notice of its scale (CRS).

11. Calculate efficiency scores for output $\mathrm{j}^{\text {th }}: \mathrm{j}=1, . ., L$. The efficiency scores take values between 0 and 1 . This maximum score is assigned to the unit used for the correction in each cluster.

$$
\begin{aligned}
& F_{\mathrm{ij}}=P_{\mathrm{ij}} /\left(P_{\left(\mathrm{ANN}^{*}\right) \mathrm{ji}}+S h_{\mathrm{ijj}}\right) \\
& i=1, \ldots, n
\end{aligned}
$$

12. Calculate final efficiency scores by (7):

$$
\begin{aligned}
& F_{\mathrm{i}}=\operatorname{AVE}\left(F_{\mathrm{i} 1}, F_{\mathrm{i} 2}, \ldots, F_{\mathrm{iL}}\right) \\
& i=1, \ldots, n
\end{aligned}
$$

13. Create corrupted and noisy data for each AIS by significantly increasing or decreasing its original (say by a multiple of 10).

14. Evaluate the efficiency scores with corrupted data (repeat steps 6 to 11).

15. Evaluate efficiency scores by DEA with corrupted data.

16. Compare the results of integrated algorithm with DEA (from steps 14 and 15) through error analysis (MAPE).

17. Select the preferred approach (the proposed algorithm or DEA) for future decision analysis.

\section{EXPERIMENT: AUTO INDUSTRY}

Automotive industries play an important role in the overall economic development. Due to the ever-increasing growth and development of automotive industry in the world, determining the position of automotive industry is very important. Therefore, the need for an integrated approach for continuous assessment and improvement of automotive industries based on economic performance becomes essential. Consequently, it will enable predictions to be made about manufacturing system behavior (Azadeh et al., 2011[2]).

A. Execution of the Integrated Algorithm

Step 1: The indicators (inputs and outputs), which influence overall management performance of auto industry sectors are collected. The data related to 12 countries for 6 years are collected. The indicators are listed as follows:

Inputs:

$\boldsymbol{x}_{1}=$ Wage and salary $(\$)$

$\boldsymbol{x}_{2}=$ Human cost

$\boldsymbol{x}_{3}=$ Number of employees

Outputs:

$\mathbf{y}_{\mathbf{1}}=$ Value added $(\$)$

$\boldsymbol{y}_{2}=$ Production volume $(\$)$

Step 2: Table I shows the actual data for inputs and outputs in year 2000.

Step 3: $S_{I}$ is data from 11 countries from 1996 to 1999 and $S_{2}$ is 2000 data (12 rows).

Steps 4-5: The preferred ANN for the auto industries is identified. The architecture of MLP and MAPE values for

TABLE I

STANDARDIZED MATRIX OF AUTO INDUSTRIES

\begin{tabular}{|c|l|c|c|c|c|}
\hline No. & \multicolumn{1}{|c|}{ Country } & $\mathrm{x}_{1}$ & $\mathrm{x}_{2}$ & $\mathrm{y}_{1}$ & $\mathrm{y}_{2}$ \\
\hline 1 & Australia & 0.0118 & 0.0803 & 0.0075 & 0.0118 \\
\hline 2 & France & 0.1070 & 0.0957 & 0.0892 & 0.2298 \\
\hline 3 & Japan & 0.2599 & 0.2729 & 0.2880 & 0.4803 \\
\hline 4 & Spain & 0.0495 & 0.0792 & 0.0398 & 0.0825 \\
\hline 5 & United Kingdom & 0.0976 & 0.0596 & 0.0388 & 0.1086 \\
\hline 6 & United States & 0.5039 & 0.2361 & 0.5795 & 0.9840 \\
\hline 7 & Republic of Korea & 0.0474 & 0.1531 & 0.0761 & 0.0741 \\
\hline 8 & Germany & 0.5814 & 0.0648 & 0.2109 & 0.4041 \\
\hline 9 & Italy & 0.0437 & 0.0503 & 0.0257 & 0.0682 \\
\hline 10 & Canada & 0.0541 & 0.3356 & 0.1077 & 0.1499 \\
\hline 11 & Malaysia & 0.0021 & 0.0391 & 0.0034 & 0.0098 \\
\hline 12 & Brazil & 0.0376 & 0.0610 & 0.0386 & 0.0339 \\
\hline
\end{tabular}


TABLE II

ARCHITECTURE OF THE ANN MODELS AND ERRORS

\begin{tabular}{|l|l|l|l|l|}
\hline Model & $\begin{array}{c}\text { Number } \\
\text { of } \\
\text { Hidden } \\
\text { Units }\end{array}$ & $\begin{array}{c}\text { Hidden } \\
\text { Layer } \\
\text { Activation } \\
\text { Fun }\end{array}$ & Learning Method & MAPE \\
\hline 1 & 8 & Tansig & $\begin{array}{l}\text { Back propagation } \\
\text { Use momentum term }\end{array}$ & 0.1054 \\
\cline { 2 - 5 } 2 & 22 & Tansig & $\begin{array}{l}\text { Back propagation } \\
\text { Use momentum term }\end{array}$ & 0.4620 \\
\cline { 2 - 5 } 3 & 32 & Tansig & $\begin{array}{l}\text { Back propagation } \\
\text { Use momentum term }\end{array}$ & 0.9309 \\
\cline { 2 - 5 } 4 & 9 & Logsig & $\begin{array}{l}\text { Back propagation } \\
\text { Use momentum term }\end{array}$ & 0.1868 \\
\cline { 2 - 6 } 5 & 19 & Logsig & $\begin{array}{l}\text { Back propagation } \\
\text { Use momentum term }\end{array}$ & 0.1799 \\
\cline { 2 - 5 } 6 & 33 & Logsig & $\begin{array}{l}\text { Back propagation } \\
\text { Use momentum term }\end{array}$ & 0.5008 \\
\cline { 2 - 6 } 7 & 5 & Logsig & $\begin{array}{l}\text { Resilient } \\
\text { backpropagation }\end{array}$ & 0.1847 \\
\cline { 2 - 5 } 8 & 5 & Tansig & $\begin{array}{l}\text { Resilient } \\
\text { backpropagation }\end{array}$ & 0.2049 \\
\hline
\end{tabular}

Selected networks are shown in Table II. It is seen that the 1 st model has lowest MAPE values.

Steps 6-10: The result of steps 6, 7, 8, 9, 10 are shown in Table III.

Step 11-12: Efficiency scores are calculated by (6) and (7). The result of this step is shown in Table IV.

TABLE III

CALCULATING EFFICIENCY FOR ALL COUNTRIES BY MEANS OF THE PROPOSED ALGORITHM

\begin{tabular}{|l|l|c|c|c|}
\hline \multirow{2}{*}{ No. } & \multicolumn{1}{|c|}{ Country } & $\mathrm{F}_{\mathrm{i}}\left(y_{l}\right)$ & $\mathrm{F}_{\mathrm{i}}\left(y_{2}\right)$ & $\begin{array}{c}\text { Efficiency } \\
\text { scores }\end{array}$ \\
\hline 1 & Austria & 1.00 & 0.16 & 1.00 \\
\cline { 2 - 5 } 2 & France & 0.72 & 0.79 & 0.89 \\
\cline { 2 - 5 } 3 & Japan & 0.93 & 0.81 & 0.94 \\
\cline { 2 - 5 } 4 & Spain & 0.83 & 0.64 & 0.95 \\
\cline { 2 - 5 } 5 & United Kingdom & 0.84 & 0.70 & 0.91 \\
\cline { 2 - 5 } 6 & United States & 1.00 & 1.00 & 1.00 \\
\cline { 2 - 5 } 7 & Republic of Korea & 1.00 & 0.21 & 0.86 \\
\cline { 2 - 5 } 8 & Germany & 0.67 & 0.57 & 0.78 \\
\cline { 2 - 5 } 9 & Italy & 0.49 & 0.28 & 0.79 \\
\cline { 2 - 5 } 10 & Canada & 0.92 & 0.15 & 0.76 \\
\cline { 2 - 5 } 11 & Malaysia & 0.41 & 0.10 & 0.74 \\
\cline { 2 - 5 } 12 & Brazil & 0.66 & 0.31 & 0.76 \\
\hline
\end{tabular}

TABLE IV

EFFICIENCY SCORES RESULTS

\begin{tabular}{|l|c|c|}
\hline \multicolumn{1}{|c|}{ Country } & $\begin{array}{c}\text { Efficiency scores } \\
\text { by conventional } \\
\text { algorithm (ANN) }\end{array}$ & $\begin{array}{c}\text { Efficiency scores by } \\
\text { the proposed } \\
\text { algorithm }\end{array}$ \\
\hline Austria & 1.00 & 1.00 \\
\hline France & 0.78 & 0.89 \\
\hline Japan & 0.91 & 0.94 \\
\hline Spain & 0.79 & 0.95 \\
\hline United Kingdom & 0.73 & 0.91 \\
\hline United States & 0.88 & 1.00 \\
\hline Republic of Korea & 0.60 & 0.86 \\
\hline Germany & 0.62 & 0.78 \\
\hline Italy & 0.39 & 0.79 \\
\hline Canada & 0.50 & 0.76 \\
\hline Malaysia & 0.22 & 0.74 \\
\hline Brazil & 0.43 & 0.76 \\
\hline Mean & 0.65 & 0.865 \\
\hline
\end{tabular}

Step 13: The capability of proposed algorithm in handling outliers and corrupted data is presented. It is assumed that imaginary outlier data is yielded from human error. Also, it is assumed that outlier or corrupted data is occurred in inputs variables. To this end, inputs variable of each AIS are multiplied by 0.1 .

Steps 14-15: All AISs (Countries) are examined in this section. The results of proposed algorithm and DEA with respect to error analysis are shown in Tables $\mathrm{V}$ and VI respectively.

Step 16: MAPE is used to compare the results. Table VII shows the MAPE value for proposed algorithm and DEA for all of DMUs (countries). Examination of MAPE values shows that the proposed algorithm is 18 times better than DEA, in average. These 12 samples show that the results of proposed algorithm are more robust than the DEA.

TABLE V

THE IMPACT OF CORRUPTED DATA ON PROPOSED ALGORITHM RESULT

\begin{tabular}{|l|c|c|c|c|}
\hline \multicolumn{1}{|c|}{$\begin{array}{c}\text { DMU } \\
\text { Name }\end{array}$} & $\begin{array}{c}\text { Efficiency } \\
\text { scores after } \\
\text { Australia } \\
\text { noise }\end{array}$ & $\begin{array}{c}\text { Efficiency } \\
\text { score after } \\
\text { France } \\
\text { noise }\end{array}$ & $\begin{array}{c}\text { Efficiency } \\
\text { score after } \\
\text { Japan } \\
\text { noise }\end{array}$ & $\begin{array}{c}\text { Original } \\
\text { efficiency } \\
\text { score }\end{array}$ \\
\hline Austria & 1.000 & 1.000 & 1.000 & 1.000 \\
\hline France & 0.867 & 1.000 & 0.891 & 0.891 \\
\hline Japan & 0.923 & 0.778 & 1.000 & 0.937 \\
\hline Spain & 0.942 & 0.819 & 0.653 & 0.935 \\
\hline $\begin{array}{l}\text { United } \\
\text { Kingdom }\end{array}$ & 0.900 & 0.810 & 0.662 & 0.909 \\
\hline $\begin{array}{l}\text { United } \\
\text { States }\end{array}$ & 1.000 & 1.000 & 0.875 & 1.000 \\
\hline $\begin{array}{l}\text { Republic } \\
\text { of Korea }\end{array}$ & 0.864 & 0.864 & 0.858 & 0.864 \\
\hline Germany & 0.780 & 0.780 & 0.777 & 0.780 \\
\hline Italy & 0.795 & 0.795 & 0.793 & 0.795 \\
\hline Canada & 0.765 & 0.765 & 0.761 & 0.765 \\
\hline Malaysia & 0.736 & 0.736 & 0.734 & 0.736 \\
\hline Brazil & 0.758 & 0.758 & 0.756 & 0.758 \\
\hline
\end{tabular}

TABLE V

THE IMPACT OF CORRUPTED DATA ON PROPOSED ALGORITHM RESULT (CONTINUE)

\begin{tabular}{|l|c|c|c|c|}
\hline $\begin{array}{c}\text { DMU } \\
\text { Name }\end{array}$ & $\begin{array}{c}\text { Efficiency } \\
\text { scores after } \\
\text { Spain noise }\end{array}$ & $\begin{array}{c}\text { Efficiency } \\
\text { score after } \\
\text { United } \\
\text { Kingdom } \\
\text { noise }\end{array}$ & $\begin{array}{c}\text { Efficiency } \\
\text { score after } \\
\text { Republic of } \\
\text { Korea } \\
\text { noise }\end{array}$ & $\begin{array}{c}\text { Original } \\
\text { efficiency } \\
\text { score }\end{array}$ \\
\hline Austria & 1.000 & 1.000 & 1.000 & 0.580 \\
\hline France & 0.891 & 0.891 & 0.891 & 0.755 \\
\hline Japan & 0.937 & 0.937 & 0.937 & 0.870 \\
\hline Spain & 1.000 & 0.953 & 0.953 & 0.735 \\
\hline $\begin{array}{l}\text { United } \\
\text { Kingdom }\end{array}$ & 0.673 & 1.000 & 0.909 & 0.770 \\
\hline $\begin{array}{l}\text { United } \\
\text { States }\end{array}$ & 0.916 & 0.873 & 1.000 & 1.000 \\
\hline $\begin{array}{l}\text { Republic } \\
\text { of Korea }\end{array}$ & 0.856 & 0.846 & 1.000 & 0.605 \\
\hline Germany & 0.769 & 0.757 & 0.596 & 0.620 \\
\hline Italy & 0.795 & 0.795 & 0.624 & 0.385 \\
\hline Canada & 0.765 & 0.765 & 0.638 & 0.535 \\
\hline Malaysia & 0.736 & 0.736 & 0.610 & 0.255 \\
\hline Brazil & 0.758 & 0.758 & 0.635 & 0.485 \\
\hline
\end{tabular}


TABLE V

THE IMPACT OF CORRUPTED DATA ON PROPOSED ALGORITHM RESULT (CONTINUE)

\begin{tabular}{|l|c|c|c|c|}
\hline \multicolumn{1}{|c|}{$\begin{array}{c}\text { DMU } \\
\text { Name }\end{array}$} & $\begin{array}{c}\text { Efficiency } \\
\text { scores after } \\
\text { Germany } \\
\text { noise }\end{array}$ & $\begin{array}{c}\text { Efficiency } \\
\text { score after } \\
\text { Italy noise }\end{array}$ & $\begin{array}{c}\text { Efficiency } \\
\text { score after } \\
\text { Canada } \\
\text { noise }\end{array}$ & $\begin{array}{c}\text { Original } \\
\text { efficiency } \\
\text { score }\end{array}$ \\
\hline Austria & 1.000 & 1.000 & 1.000 & 0.580 \\
\hline France & 0.891 & 0.891 & 0.891 & 0.755 \\
\hline Japan & 0.937 & 0.937 & 0.937 & 0.870 \\
\hline Spain & 0.953 & 0.953 & 0.953 & 0.735 \\
\hline $\begin{array}{l}\text { United } \\
\text { Kingdom }\end{array}$ & 0.909 & 0.909 & 0.909 & 0.770 \\
\hline $\begin{array}{l}\text { United } \\
\text { States }\end{array}$ & 1.000 & 1.000 & 1.000 & 1.000 \\
\hline $\begin{array}{l}\text { Republic } \\
\text { of Korea }\end{array}$ & 0.864 & 0.864 & 0.864 & 0.605 \\
\hline Germany & 0.938 & 0.780 & 0.780 & 0.620 \\
\hline Italy & 0.625 & 0.930 & 0.795 & 0.385 \\
\hline Canada & 0.765 & 0.663 & 1.000 & 0.535 \\
\hline Malaysia & 0.618 & 0.603 & 0.585 & 0.255 \\
\hline Brazil & 0.654 & 0.641 & 0.601 & 0.485 \\
\hline
\end{tabular}

TABLE V

THE IMPACT OF CORRUPTED DATA ON PROPOSED ALGORITHM RESULT (CONTINUE)

\begin{tabular}{|l|c|c|c|c|}
\hline \multicolumn{1}{|c|}{$\begin{array}{c}\text { DMU } \\
\text { Name }\end{array}$} & $\begin{array}{c}\text { Efficiency } \\
\text { scores after } \\
\text { Malaysia } \\
\text { noise }\end{array}$ & $\begin{array}{c}\text { Efficiency } \\
\text { score after } \\
\text { USA noise }\end{array}$ & $\begin{array}{c}\text { Efficiency } \\
\text { score after } \\
\text { Brazil } \\
\text { noise }\end{array}$ & $\begin{array}{c}\text { Original } \\
\text { efficiency } \\
\text { score }\end{array}$ \\
\hline Austria & 1.000 & 1.000 & 1.000 & 0.580 \\
\hline France & 0.891 & 0.891 & 0.891 & 0.755 \\
\hline Japan & 0.937 & 0.937 & 0.937 & 0.870 \\
\hline Spain & 0.953 & 0.953 & 0.953 & 0.735 \\
\hline $\begin{array}{l}\text { United } \\
\text { Kingdom }\end{array}$ & 0.909 & 0.909 & 0.909 & 0.770 \\
\hline $\begin{array}{l}\text { United } \\
\text { States }\end{array}$ & 1.000 & 0.985 & 1.000 & 1.000 \\
\hline $\begin{array}{l}\text { Republic } \\
\text { of Korea }\end{array}$ & 0.864 & 0.509 & 0.864 & 0.605 \\
\hline Germany & 0.780 & 0.575 & 0.780 & 0.620 \\
\hline Italy & 0.795 & 0.610 & 0.795 & 0.385 \\
\hline Canada & 0.765 & 0.479 & 0.765 & 0.535 \\
\hline Malaysia & 0.778 & 0.544 & 0.736 & 0.255 \\
\hline Brazil & 0.683 & 0.523 & 1.000 & 0.485 \\
\hline
\end{tabular}

TABLE VI

THE IMPACT OF CORRUPTED DATA ON DEA RESULT

\begin{tabular}{|l|c|c|c|c|}
\hline \multicolumn{1}{|c|}{ DMU } & $\begin{array}{c}\text { Efficiency } \\
\text { scores after } \\
\text { Australia } \\
\text { noise }\end{array}$ & $\begin{array}{c}\text { Efficiency } \\
\text { score after } \\
\text { France } \\
\text { noise }\end{array}$ & $\begin{array}{c}\text { Efficiency } \\
\text { score after } \\
\text { Japan } \\
\text { noise }\end{array}$ & $\begin{array}{c}\text { Original } \\
\text { efficiency } \\
\text { score }\end{array}$ \\
\hline Austria & 1.000 & 1.000 & 1.000 & 1.000 \\
\hline France & 0.230 & 1.000 & 0.353 & 0.377 \\
\hline Japan & 0.075 & 0.116 & 1.000 & 0.133 \\
\hline Spain & 0.155 & 0.190 & 0.338 & 0.377 \\
\hline $\begin{array}{l}\text { United } \\
\text { Kingdom }\end{array}$ & 0.230 & 0.155 & 0.359 & 0.388 \\
\hline $\begin{array}{l}\text { United } \\
\text { States }\end{array}$ & 0.291 & 0.206 & 0.326 & 0.343 \\
\hline $\begin{array}{l}\text { Republic } \\
\text { of Korea }\end{array}$ & 0.255 & 0.343 & 0.341 & 0.436 \\
\hline Germany & 0.186 & 0.106 & 0.300 & 0.353 \\
\hline Italy & 0.278 & 0.189 & 0.473 & 0.557 \\
\hline Canada & 0.094 & 0.322 & 0.309 & 0.335 \\
\hline Malaysia & 1.000 & 1.000 & 1.000 & 1.000 \\
\hline Brazil & 0.626 & 0.565 & 0.645 & 0.653 \\
\hline
\end{tabular}

TABLE VI

THE IMPACT OF CORRUPTED DATA ON DEA RESULT (CONTINUE)

\begin{tabular}{|l|c|c|c|c|}
\hline \multicolumn{1}{|c|}{$\begin{array}{c}\text { DMU } \\
\text { Name }\end{array}$} & $\begin{array}{c}\text { Efficiency } \\
\text { scores after } \\
\text { Spain noise }\end{array}$ & $\begin{array}{c}\text { Efficiency } \\
\text { score after } \\
\text { United } \\
\text { Kingdom } \\
\text { noise }\end{array}$ & $\begin{array}{c}\text { Efficiency } \\
\text { score after } \\
\text { Republic of } \\
\text { Korea } \\
\text { noise }\end{array}$ & $\begin{array}{c}\text { Original } \\
\text { efficiency } \\
\text { score }\end{array}$ \\
\hline Austria & 0.884 & 1.000 & 0.819 & 1.000 \\
\hline France & 0.175 & 0.101 & 0.161 & 0.377 \\
\hline Japan & 0.089 & 0.108 & 0.051 & 0.133 \\
\hline Spain & 1.000 & 0.161 & 0.154 & 0.377 \\
\hline $\begin{array}{l}\text { United } \\
\text { Kingdom }\end{array}$ & 0.176 & 1.000 & 0.164 & 0.388 \\
\hline $\begin{array}{l}\text { United } \\
\text { States }\end{array}$ & 0.268 & 0.205 & 0.175 & 0.343 \\
\hline $\begin{array}{l}\text { Republic } \\
\text { of Korea }\end{array}$ & 0.279 & 0.254 & 1.000 & 0.436 \\
\hline Germany & 0.147 & 0.091 & 0.127 & 0.353 \\
\hline Italy & 0.216 & 0.144 & 0.210 & 0.557 \\
\hline Canada & 0.221 & 0.307 & 0.172 & 0.335 \\
\hline Malaysia & 1.000 & 1.000 & 1.000 & 1.000 \\
\hline Brazil & 0.613 & 0.564 & 0.533 & 0.653 \\
\hline
\end{tabular}

TABLE VI

THE IMPACT OF CORRUPTED DATA ON DEA RESULT (CONTINUE)

\begin{tabular}{|l|c|c|c|c|}
\hline $\begin{array}{c}\text { DMU } \\
\text { Name }\end{array}$ & $\begin{array}{c}\text { Efficiency } \\
\text { scores after } \\
\text { Germany } \\
\text { noise }\end{array}$ & $\begin{array}{c}\text { Efficiency } \\
\text { score after } \\
\text { Italy noise }\end{array}$ & $\begin{array}{c}\text { Efficiency } \\
\text { score after } \\
\text { Canada } \\
\text { noise }\end{array}$ & $\begin{array}{c}\text { Original } \\
\text { efficiency } \\
\text { score }\end{array}$ \\
\hline Austria & 1.000 & 1.000 & 0.827 & 1.000 \\
\hline France & 0.172 & 0.089 & 0.307 & 0.377 \\
\hline Japan & 0.125 & 0.101 & 0.109 & 0.133 \\
\hline Spain & 0.262 & 0.147 & 0.297 & 0.377 \\
\hline $\begin{array}{l}\text { United } \\
\text { Kingdom }\end{array}$ & 0.206 & 0.102 & 0.353 & 0.388 \\
\hline $\begin{array}{l}\text { United } \\
\text { States }\end{array}$ & 0.228 & 0.189 & 0.336 & 0.343 \\
\hline $\begin{array}{l}\text { Republic } \\
\text { of Korea }\end{array}$ & 0.361 & 0.253 & 0.372 & 0.436 \\
\hline Germany & 1.000 & 0.070 & 0.316 & 0.353 \\
\hline Italy & 0.253 & 1.000 & 0.493 & 0.557 \\
\hline Canada & 0.355 & 0.299 & 1.000 & 0.335 \\
\hline Malaysia & 1.000 & 1.000 & 1.000 & 1.000 \\
\hline Brazil & 0.584 & 0.548 & 0.649 & 0.653 \\
\hline
\end{tabular}

TABLE VI

THE IMPACT OF CORRUPTED DATA ON DEA RESULT (CONTINUE)

\begin{tabular}{|l|c|c|c|c|}
\hline \multicolumn{1}{|c|}{$\begin{array}{c}\text { DMU } \\
\text { Name }\end{array}$} & $\begin{array}{c}\text { Efficiency } \\
\text { scores after } \\
\text { Malaysia } \\
\text { noise }\end{array}$ & $\begin{array}{c}\text { Efficiency } \\
\text { score after } \\
\text { USA noise }\end{array}$ & $\begin{array}{c}\text { Efficiency } \\
\text { score after } \\
\text { Brazil } \\
\text { noise }\end{array}$ & $\begin{array}{c}\text { Original } \\
\text { efficiency } \\
\text { score }\end{array}$ \\
\hline Austria & 0.353 & 1.000 & 1.000 & 1.000 \\
\hline France & 0.038 & 0.366 & 0.105 & 0.377 \\
\hline Japan & 0.019 & 0.133 & 0.109 & 0.133 \\
\hline Spain & 0.041 & 0.375 & 0.183 & 0.377 \\
\hline $\begin{array}{l}\text { United } \\
\text { Kingdom }\end{array}$ & 0.039 & 0.388 & 0.121 & 0.388 \\
\hline $\begin{array}{l}\text { United } \\
\text { States }\end{array}$ & 0.034 & 1.000 & 0.087 & 0.343 \\
\hline $\begin{array}{l}\text { Republic } \\
\text { of Korea }\end{array}$ & 0.057 & 0.436 & 0.251 & 0.436 \\
\hline Germany & 0.035 & 0.353 & 0.069 & 0.353 \\
\hline Italy & 0.056 & 0.557 & 0.148 & 0.557 \\
\hline Canada & 0.058 & 0.335 & 0.318 & 0.335 \\
\hline Malaysia & 1.000 & 1.000 & 1.000 & 1.000 \\
\hline Brazil & 0.065 & 0.653 & 1.000 & 0.653 \\
\hline
\end{tabular}


TABLE VII

THE MAPE VALUE FOR EACH DMU'S (CORRUPTED DATA) IN PROPOSED

\begin{tabular}{|l|c|c|c|}
\hline \multicolumn{1}{|c|}{$\begin{array}{c}\text { DMU } \\
\text { Name }\end{array}$} & $\begin{array}{c}\text { MAPE of } \\
\text { proposed } \\
\text { algorithm(A) }\end{array}$ & $\begin{array}{c}\text { MAPE of } \\
\text { DEA(B) }\end{array}$ & $\begin{array}{c}\text { Relative Efficiency of the } \\
\text { Algorithm Over } \\
\text { DEA(A/B) }\end{array}$ \\
\hline Austria & 0.005 & 0.344 & 69 \\
\hline France & 0.045 & 0.419 & 9 \\
\hline Japan & 0.067 & 0.618 & 9 \\
\hline Spain & 0.035 & 0.446 & 13 \\
\hline $\begin{array}{l}\text { United } \\
\text { Kingdom }\end{array}$ & 0.023 & 0.466 & 1 \\
\hline $\begin{array}{l}\text { United } \\
\text { States }\end{array}$ & 0.156 & 0.162 & 6 \\
\hline $\begin{array}{c}\text { Republic } \\
\text { of Korea }\end{array}$ & 0.092 & 0.522 & 5 \\
\hline Germany & 0.069 & 0.364 & 8 \\
\hline Italy & 0.053 & 0.424 & 4 \\
\hline Canada & 0.060 & 0.269 & 61 \\
\hline Malaysia & 0.013 & 0.791 & 17 \\
\hline Brazil & 0.027 & 0.450 & \\
\hline
\end{tabular}

\section{CONCLUSION}

Parametric approach was proposed to measure and rank the auto industry sector (in selected countries) efficiency based on a highly unique flexible ANN algorithm regarding to its non-linearity and flexibility. Have a noisy environment is an inevitable issue in the auto industry sector (AIS) and developing the flexible method so helpful. To deal with this issue, the 16 steps algorithm based on artificial neural network has been proposed. Also, for the first time, multiple output situations are considered in the developed algorithm. To show its applicability and superiority in the AIS, it was applied to auto industries in some selected countries around the world in the years 1995 to 2000. Austria, France, Japan, Spain, United Kingdom, United States, Republic of Korea, Germany, Italy, Canada, Malaysia and Brazil are 12 selected countries. To test the robustness of the efficiency results of the proposed method, the ability of proposed ANN algorithm in dealing with noisy and corrupted data is compared with Data Envelopment Analysis (Steps 13-16). Results of the robustness check show that the proposed algorithm is much more robust to the noise and corruption in input data than DEA. Average percentage changes in efficiency scores of DEA are 18 times greater than the changes in efficiency scores of the proposed ANN.

Future research with neural networks in assessing its ability with dealing various noise distributions is proposed. Also, future studies can use more output or input indicators to reach a realistic model.

\section{REFERENCES}

[1] Azadeh, M.A. (2000). Creating Highly Reliable Manufacturing Systems: An Integrated Approach, International Journal of Reliability, Quality and Safety Engineering, 7(3):205-222.

[2] Azadeh A, Saberi M, Anvari M., (2011), An Integrated Artificial Neural Network Fuzzy C-Means-Normalization Algorithm for performance assessment of decision-making units: The cases of auto industry and power plant, Computers \& Industrial Engineering, Pages 328-340.

[3] Lawrence M. Seiford (1997), A bibliography for Data Envelopment Analysis (1978 -1996), Annals of Operations Research, 73393 - 438.

[4] Hung-Yi Wu, Yi-Kuei Lin, Chi-Hsiang Chang (2011), Performance evaluation of extension education centers in universities based on the balanced scorecard, Evaluation and Program Planning, 34 37-50.

[5] Tian-Hong Pan, Shyan-Shu Shieh, Shi-Shang Jang, Wen-Hung Tseng ,Chan-Wei Wud, Jenq-Jang Oud (2011), Statistical multi-model approach for performance assessment of cooling tower, Energy Conversion and Management, 52 1377-1385.

[6] Wei-Zhen Lu , Hong-Di He, Li-yun Dong (2011), Performance assessment of air quality monitoring networks using principal component analysis and cluster analysis, Building and Environment, 46 577-583.

[7] Bruce Hollingsworth, P.J. Dawson and N. Maniadakis (1999), Efficiency measurement of health care: a review of non-parametric methods and applications, Health Care Management Science, 2 161172 .

[8] Bruce Hollingsworth (2006), Non-Parametric and Parametric Applications Measuring Efficiency in Health Care, Health Care Management Science, 6, 203-218, 2003.

[9] A.S. Camanho - R. G. Dyson, (2006), Data envelopment analysis and Malmquist indices for measuring group performance, J Prod Anal, 26:35-49.

[10] Feng Yang · Dexiang Wu · Liang Liang · Gongbing Bi · Desheng DashWu, Supply chain DEA: production possibility set and performance evaluation model, Ann Oper Res, in press.

[11] Athanassopoulos, A.D., Curram, S.P. (1996). A comparison of data envelopment analysis and artificial neural networks as tool for assessing the efficiency of decision making units, Journal of the Operational Research Society, 47 (8):1000-1016.

[12] Costa, A., Markellos, R.N. (1997) Evaluating public transport efficiency with neural network models, Transportation Research $C 5$ (5):301-312.

[13] Santın, D., Valin, A. (2000). Artificial Neural Networks for Measuring Technical Efficiency in Schools with a Two-Level Model: an Alternative Approach, II Oviedo Workshop on Efficiency and Productivity, Oviedo. 